\title{
KEMAMPUAN PEMECAHAN MASALAH MATEMATIKA BERDASARKAN TEORI POLYA MELALUI PENERAPAN MODEL PEMBELAJARAN KOOPERATIF TIPE TGT
}

\author{
Billy Alexa Bellvian', Haryanto ${ }^{2 *}$, Andi Fajeriani Wirasty ${ }^{3}$ \\ 1,2,3 Jurusan Pendidikan Matematika, FKIP Universitas Papua \\ Jalan Tugu Jepang Amban Manokwari Papua Barat, Indonesia \\ e-mail: ${ }^{2}$ harry_mat_unipa@yahoo.com; \\ Submitted: October 08, 2021 \\ Revised: October 28, 2021 \\ Accepted: November 16, 2021 \\ corresponding author*
}

\begin{abstract}
Abstrak
Tujuan penelitian ini untuk mengetahui kemampuan pemecahan masalah matematika siswa kelas XI IPA III SMA N 2 Manokwari pada materi penerapan turunan berdasarkan teori Polya melalui penerapan model pembelajaran kooperatif tipe teams games tournament (TGT). Penelitian ini menggunakan metode kualitatif dengan menggunakan teknik deskriptif. Hasil penelitian ini menunjukkan bahwa dalam mengerjakan soal, siswa tidak mengacu kepada teori pemecahan masalah matematika menurut Polya secara sempurna. Terjadinya kelemahan ini disebabkan penerapan model pembelajaran kooperatif tipe TGT mengharuskan siswa mengerjakan soal dengan memanfaatkan waktu seefisien mungkin.
\end{abstract}

Kata Kunci: kemampuan pemecahan masalah matematis, teori polya, model tgt

\section{THE ABILITY IN SOLVING MATHEMATICAL BASED ON THE THEORY OF POLYA AFTER APPLYING KOOPERATIVE LEARNING MODEL TGT TIPE}

\begin{abstract}
The purpose from this research is to knowing the abilities of mathematical problem's solving in applications of derivates after used team game tournament cooperative learning (TGT) on students of XI SCIENCE III class of SMAN 2 Manokwari. Research's method which be used is qualitative research's method with descriptive's technique. This research shows that in doing the test, students don't uses the theory of mathematic's problem's solving from Polya perfectly. This is caused the usage from TGT's type of cooperative learning model makes students to do the test by utilizing time as efficiently as possible.
\end{abstract}

Keywords: ability of mathematic's problem's solving, polya's theory, tgt model

\section{Pendahuluan}

Kemampuan pemecahan masalah merupakan proses yang tidak terpisahkan dari setiap aktivitas manusia terutama bagi siswa. Salah satunya karena setiap manusia tidak terlepas dari permasalahan dalam menjalani kehidupannya. Menghadapi setiap permasalahan yang ada, dibutuhkan cara-cara untuk memecahkan permasalahan yang dihadapi, tak terkecuali permasalahan matematika.

Permasalahan dalam matematika diinterpretasikan secara berbeda oleh individu yang menghadapinya (Laamena dan Laurens, 2021). Menurut Schoenfeld dalam Laamena dan Laurens (2021) masalah matematika bagi siswa adalah tugas-tugas yang: (1) menarik perhatian siswa dan menantang mereka untuk menyelesaikannya, (2) tidak mudah mencari solusi. Masalah sebagai situasi yang membutuhkan penyelesaian dan cara penyelesaiannya belum jelas atau nyata sehingga siswa perlu untuk mencari solusi.

Menurut Lutfiyah (2020, 7), masalah matematika adalah persoalan matematika yang menunjukkan adanya tantangan, tidak mudah diselesaikan dan memerlukan perencanaan yang tepat. Menurut Tohir dalam Aini dan Mukhlis (2020, 106), masalah matematika adalah masalah yang membutuhkan teknik tertentu untuk memecahkannya. Dari pendapat para ahli, maka masalah matematika adalah persoalan matematika 
yang jelas tujuannya, namun tidak mudah untuk menemukan solusinya karena kurangnya algoritma yang diketahui untuk menyelesaikannya. Mengatasinya dibutuhkan kemampuan dalam memecahkan masalah.

Menurut Polya dalam Lestari \& Sofyan (2014, 98), pemecahan masalah adalah suatu tingkat aktivitas intelektual siswa untuk mencari penyelesaian masalah yang dihadapi dengan menggunakan bekal pengetahuan yang sudah dimiliki. Menurut Ilmiyana (2018, 19), kemampuan pemecahan masalah adalah kesanggupan individu dalam mencari jalan keluar dari masalah yang dihadapinya untuk memperoleh pengetahuan dan konsep berpikir secara ilmiah. Pendapat ahli di atas, maka kemampuan pemecahan masalah dapat diartikan sebagai kesanggupan yang berhubungan dengan aktivitas intelektual untuk mencari solusi dari masalah yang dihadapinya.

Kemampuan pemecahan masalah matematika sangat penting. Mengingat bahwa matematika penting untuk di kuasai, maka seorang guru perlu menanamkan dasar matematika yang kuat terhadap siswanya. Pernyataan ini sejalan dengan pernyataan Munirah $(2015,14)$ bahwa dalam mengajarkan konsep dasar matematika kepada siswa secara bermakna.

Kemampuan pemecahan masalah matematika dari siswa masih tergolong dalam kategori rendah. Pertama, hal ini dapat diketahui berdasarkan hasil penelitian dari Padillah dkk (2018) dalam penelitiannya yang berjudul "analisis kemampuan pemecahan masalah dan disposisi matematika siswa kelas XI SMA Putra Juang dalam materi peluang". Hasil penelitian tersebut diperoleh bahwa kemampuan pemecahan masalah pada siswa kelas XI tentang materi peluang dalam kategori rendah. Ini terlihat dari kebanyaknya siswa mencapai poin $48,75 \%$ pada indikator memahami masalah, $40 \%$ pada merencanakan penyelesaian, $7,5 \%$ pada menyelesaikan masalah, dan $0 \%$ pada melakukan pengecekan. Kedua, penelitian yang dilakukan oleh Luthfiyah (2020) dalam penelitiannya yang berjudul "Analisis Kemampuan Pemecahan Masalah Matematika Berdasarkan Teori Polya Pada Siswa Kelas VIII SMP IT Insan Mulia Manokwari". Hasil penelitian tersebut dianalisis hasil pengerjaan soal yang dilakukan oleh tiga orang subjek. Salah satu subjek dalam penelitiannya diberi simbol S9. Dalam penelitianya, ditemukan fakta bahwa S9 sama sekali tidak dapat menyelesaikan soal yang diberikan jika ditinjau dari empat indikator pemecahan masalah matematika menurut teori Polya.
Penelitian ini menggunakan siswa kelas XI IPA III SMAN 2 Manokwari sebagai subjek penelitian. Penelitian tentang kemampuan pemecahan masalah matematika dalam menyelesaikan soal penerapan turunan pada siswa kelas XI IPA III SMAN 2 Manokwari. Untuk mengawali kegiatan ini dilakukan sesi wawancara dengan guru matematika Kelas XI IPA III. Beliau mengatakan bahwa terdapat beberapa siswa yang mengalami kesulitan dalam memahami materi yang sedang diajarkan. Beliau juga menambahkan bahwa salah satu materi matematika yang sulit untuk dipahami oleh siswa adalah penerapan turunan yang termasuk dalam subbab materi turunan untuk siswa Kelas XI pada semester genap. Hal tersebut dikarenakan oleh banyaknya rumus yang perlu dikuasai dan bukan dihapal sehingga mengakibatkan rendahnya kemampuan pemecahan masalah matematika siswa pada masa sebelumnya.

Setelah wawancara dengan guru matematika dilakukan observasi. Hasil observasi terdapat beberapa siswa yang tertidur saat kegiatan pembelajaran matematika sedang berlangsung. Selain itu, terdapat beberapa siswa yang asyik ngobrol dengan temannya. Melihat kenyataan tersebut, selanjutnya dipersilahkan seluruh siswa untuk menuliskan kesan-kesan siswa saat sedang diberlangsungkannya proses pembelajaran matematika. Terdapat siswa yang mengatakan mengantuk karena bosan, ada yang merasa tertekan dan tegang, ada yang merasa guru menjelaskan materi dengan cepat, dan bahkan ada yang tidak mengerti dengan cara menjelaskan dari teman siswa saat presentasi. Keadaan ini dapat berdampak pada kemampuan pemecahan masalah matematika siswa.

Hasil wawancara yang dilakukan kepada guru matematika serta observasi pendahuluan yang dilakukan, diperoleh bahwa penerapan suatu model pembelajaran memiliki dampak terhadap kemampuan pemecahan masalah matematika siswa. Kondisi ini dibutuhkan suatu model pembelajaran yang menyenangkan. Model pembelajaran ini membantu siswa untuk fokus mengikuti pembelajaran agar siswa dapat memecahkan masalah matematika dalam materi penerapan turunan yang akan diberikan. Tentunya model pembelajaran ini harus melibatkan siswa secara aktif dalam kegiatan pembelajaran. Salah satu model pembelajaran yang dapat digunakan adalah model pembelajaran kooperatif tipe TGT.

Penelitian ini menggunakan teori Polya untuk menganalisa kemampuan pemecahan masalah matematika siswa. Kegiatan ini dilakukan setelah pembelajaran matematika menggunakan model pembelajaran kooperatif tipe Teams Games Tournament (TGT). Tujuan dari penelitian ini 
untuk mengetahui tentang kemampuan pemecahan masalah matematika dari siswa XI IPA III setelah pembelajaran dengan model pembelajaran kooperatif tipe TGT.

Artikel ini membahas tentang dampak menggunakan model pembelajaran kooperatif tipe TGT terhadap kemampuan siswa dalam menyelesaikan masalah berdasarkan teori polya.

\section{Metode Penelitian}

Penelitian ini merupakan penelitian kualitatif dengan pendekatan deskriptif. Penelitian deskriptif kualitatif ini mengikuti tahapan prosedur sebagai berikut:

Tahap Persiapan dilakukan observasi pendahuluan untuk mengetahui karakteristik dari lokasi yang dijadikan sebagai lokasi peneltian. Observasi pendahuluan ini difokuskan pada pengamatan terhadap aktivitas siswa saat melaksanakan kegiatan pembelajaran matematika. Selanjutnya, disiapkan materi yang akan disajikan melalui model pembelajarann kooperatif tipe TGT dengan membuat Rancangan Pelaksanaan Pembelajaran (RPP). RPP disusun berdasarkan silabus dan mengacu kepada kurikulum 2013. Selanjutnya, disiapkan bahan ajar untuk dibahas oleh siswa secara berkelompok, masalah untuk games tournament, media pembelajaran, dan soal tes individual. Instrumen penelitian sebelum digunakan terlebih dahulu dilakukan validasi ahli.

Tahap kedua dilaksanakan kegiatan pembelajaran dengan mengikuti langkah-langkah pembelajaran kooperatif tipe TGT yang telah dirumuskan dalam RPP. Tahapan ini sebagai bentuk penerapan model pembelajaran kooperatif tipe TGT sebagai upaya mengetahui kontribusinya terhadap pencapaian kemampuan pemecahan masalah matematis siswa.

Tahapan ketiga adalah pengumpulan data. Data yang digunakan dalam penelitian ini adalah hasil tes tertulis yang dikerjakan secara individu, hasil wawancara, dan dokumentasi. Hasil tes tertulis menjadi bahan analisis yang disesuaikan dengan teori kemampuan pemecahan menurut teori Polya. Hasil wawancara dan dokumentasi digunakan dalam menganalisi hasil dari tes tertulis. Sumber data pada penelitian ini berasal dari siswa kelas XI IPA III SMAN 2 Manokwari yang menjadi subyek penelitian.

Perhitungan terhadap hasil tes kemampuan pemecahan masalah matematika menggunakan rubrik penskoran. Rubrik penskoran tersebut dapat dilihat pada Tabel 1.Adapun menghitung persentasi langkah pemecahan masalah sebagai berikut:

$$
P=\frac{\text { Jumlah skor dari setiap langkah }}{\text { Skor maksimal dari setiap langkah }} \times 100 \%
$$

Data hasil tes kemampuan pemecahan masalah yang diperoleh kemudian didukung oleh hasil wawancara dengan tidak terstruktur bersama siswa yang terpilih untuk mengetahui informasi tambahan mengenai kemampuan pemecahan masalah menurut teori Polya.

Tabel 1. Rubrik Penskoran Tes Pemecahan Masalah Matematika

\begin{tabular}{|c|c|c|}
\hline Aspek Penilaian & Skor & Keterangan \\
\hline \multirow{4}{*}{ Memahami Masalah } & 0 & $\begin{array}{l}\text { Tidak menyebutkan / menuliskan apa yang diketahui, apa yang ditanyakan, dan } \\
\text { syarat yang diperlukan untuk mengerjakan soal }\end{array}$ \\
\hline & 1 & $\begin{array}{l}\text { Menyebutkan/menuliskan apa yang diketahui, apa yang ditanyakan, dan syarat } \\
\text { yang diperlukan untuk mengerjakan soal secara kurang lengkap dan atau kurang } \\
\text { tepat }\end{array}$ \\
\hline & 2 & $\begin{array}{l}\text { Menyebutkan/menuliskan apa yang diketahui, apa yang ditanyakan, dan syarat } \\
\text { yang diperlukan untuk mengerjakan soal secara lengkap namun ada yang kurang } \\
\text { tepat. }\end{array}$ \\
\hline & 3 & $\begin{array}{l}\text { Menuliskan apa yang diketahui, apa yang ditanyakan, dan syarat yang diperlukan } \\
\text { untuk mengerjakan soal secara lengkap dan tepat. }\end{array}$ \\
\hline \multirow{5}{*}{$\begin{array}{l}\text { Membuat Rencana } \\
\text { Pemecahan Masalah }\end{array}$} & 0 & Tidak menyajikan urutan langkah penyelesaian sama sekali \\
\hline & 1 & Menyajikan urutan langkah penyelesaian yang mustahil dilakukan. \\
\hline & 2 & Menyajikan urutan langkah penyelesaian yang lengkap namun tidak tepat. \\
\hline & 3 & Menyajikan urutan langkah penyelesaian yang lengkap atau kurang tepat. \\
\hline & 4 & $\begin{array}{l}\text { Menyajikan urutan langkah penyelesaian yang benar dan mengarah pada jawaban } \\
\text { yang benar }\end{array}$ \\
\hline \multirow{2}{*}{$\begin{array}{l}\text { Melakukan Rencana / } \\
\text { Perhitungan }\end{array}$} & 0 & Tidak melakukan perhitungan \\
\hline & 1 & $\begin{array}{l}\text { Melaksanakan prosedur perhitungan secara tidak tepat, karena menggunakan rumus } \\
\text { yang tidak relevan. }\end{array}$ \\
\hline
\end{tabular}




\begin{tabular}{|c|c|c|}
\hline & 2 & $\begin{array}{l}\text { Melaksanakan prosedur perhitungan dengan rumus yang tepat, namun salah dalam } \\
\text { memilih simbol operasi matematika yang sesuai }\end{array}$ \\
\hline & 3 & $\begin{array}{l}\text { Melaksanakan prosedur perhitungan dengan rumus serta simbol operasi } \\
\text { matematika yang tepat, namun salah dalam mengoperasikan rumus yang dipilih. }\end{array}$ \\
\hline & 4 & $\begin{array}{l}\text { Melaksanakan prosedur perhitungan dengan rumus serta simbol operasi } \\
\text { matematika yang tepat, namun salah dalam pemilihan tanda }\langle,>\text {, atau }=\text {. }\end{array}$ \\
\hline & 5 & Melakukan proses yang benar namun kurang lengkap atau tidak sampai tuntas. \\
\hline & 6 & Melakukan proses yang benar namun salah dalam menulis jawaban. \\
\hline & 7 & Melakukan proses yang benar dan memperoleh jawaban yang benar. \\
\hline \multirow{5}{*}{$\begin{array}{l}\text { Memeriksa Kembali } \\
\text { Hasil }\end{array}$} & 0 & Tidak ada pemeriksaan atau tidak ada keterangan lain. \\
\hline & 1 & $\begin{array}{l}\text { Salah dalam melakukan pemeriksaan karena langkah-langkah sebelumnya telah } \\
\text { salah. }\end{array}$ \\
\hline & 2 & $\begin{array}{l}\text { Salah dalam melakukan pemeriksaan, namun langkah-langkah sebelumnya telah } \\
\text { tepat. }\end{array}$ \\
\hline & 3 & Melakukan pemeriksaan dengan tepat, namun tidak tuntas. \\
\hline & 4 & Pemeriksaan dilakukan untuk melihat kebenaran proses. \\
\hline
\end{tabular}

Data hasil tes kemampuan pemecahan masalah beserta transkrip wawancara yang diperoleh selanjutnya dilakukanlah proses analisis data. Analisis data dalam penelitian ini menggunakan prosedur analisis data dari Miles dan Hubberman dalam Ilmiyana $(2018,67)$. Prosedur analisis ini terdapat tiga tahapan yakni reduksi data, penyajian data, dan penarikan kesimpulan.

\section{Hasil dan Pembahasan}

Tabel 2. Data kemampuan pemecahan masalah oleh S4 \& S24
Penelitian ini menetapkan S4 dan S24 sebagai subjek penelitian. Subjek S4 merupakan siswa yang mendapat nilai tinggi dan $\mathrm{S} 24$ bernilai rendah pada hasil tes kemampuan pemecahan masalah matematika. Penetapan dua subjek ini didasarkan karena terdapat beberapa variasi langkah-langkah pengerjaan soal yang unik dari siswa berdua. Paparan data hasil tes kemampuan pemecahan masalah pada pokok bahasan turunan oleh kedua siswa tersebut dapat disajikan berdasarkan rubrik skor pemecahan masalah pada tabel 1. Data statistik tersebut dapat dilihat pada tabel 2. sebagai berikut:

\begin{tabular}{|c|c|c|c|c|c|c|c|c|}
\hline \multirow{3}{*}{ No Soal } & \multicolumn{8}{|c|}{$\begin{array}{l}\text { INDIKATOR PEMECAHAN MASALAH MATEMATIKA BERDASARKAN TEORI } \\
\text { POLYA }\end{array}$} \\
\hline & \multicolumn{2}{|c|}{ Memahami Masalah } & \multicolumn{2}{|c|}{$\begin{array}{l}\text { Membuat Rencana } \\
\text { Pemecahan Masalah }\end{array}$} & \multicolumn{2}{|c|}{$\begin{array}{l}\text { Melakukan Rencana } \\
\text { / Perhitungan }\end{array}$} & \multicolumn{2}{|c|}{ Memeriksa Kembali } \\
\hline & $\mathrm{S} 4$ & S24 & $\mathrm{S} 4$ & S24 & $\mathrm{S} 4$ & S24 & $\mathrm{S} 4$ & S24 \\
\hline 1 & 3 & 1 & 3 & 2 & 3 & 3 & 1 & 1 \\
\hline 2 & 2 & 3 & 3 & 2 & 4 & 3 & 3 & 1 \\
\hline 3 & 2 & 3 & 3 & 2 & 4 & 3 & 2 & 1 \\
\hline 4 & 2 & 2 & 2 & 3 & 3 & 5 & 1 & 3 \\
\hline 5 & 2 & 1 & 3 & 1 & 6 & 1 & 2 & 1 \\
\hline Jumlah total & 11 & 10 & 14 & 10 & 20 & 15 & 9 & 7 \\
\hline Persentase & $73,33 \%$ & $66,67 \%$ & $70 \%$ & $50 \%$ & $57,14 \%$ & $42,86 \%$ & $45 \%$ & $35 \%$ \\
\hline
\end{tabular}

Indikator memahami masalah, S4 memperoleh total skor sama dengan 11 dari skor total yang berjumlah 15, sehingga S4 memperoleh persentase dalam memahami masalah sebesar $73,33 \%$. Subjek S24 memperoleh total skor sama dengan 10 dari skor total yang berjumlah 15 , sehingga S24 memperoleh persentase dalam memahami masalah sebesar $66,67 \%$.
Indikator membuat rencana pemecahan masalah, S4 memperoleh total skor sama dengan 14 dari skor total yang berjumlah 20, sehingga S4 memperoleh persentase dalam membuat rencana pemecahan masalah sebesar 70\%. Subjek S24 memperoleh total skor sama dengan 10 dari skor total yang berjumlah 20, sehingga S24 memperoleh 
persentase dalam membuat rencana pemecahan masalah sebesar 50\%.

Indikator melakukan rencana / perhitungan, S4 memperoleh total skor sama dengan 20 dari skor total yang berjumlah 35 , sehingga $\mathrm{S} 4$ memperoleh persentase dalam melakukan rencana/perhitungan sebesar $57,14 \%$. Subjek S24 memperoleh total skor sama dengan 15 dari skor total yang berjumlah 35 , sehingga S24 memperoleh persentase dalam melakukan rencana / perhitungan sebesar $42,86 \%$.

Indikator memeriksa kembali, S4 memperoleh total skor sama dengan 9 dari skor total yang berjumlah 20, sehingga $\mathrm{S} 4$ memperoleh persentase dalam memeriksa kembali sebesar $45 \%$. Subjek S24 memperoleh total skor sama dengan 7 dari skor total yang berjumlah 20, sehingga S24 memperoleh persentase dalam memeriksa kembali sebesar $35 \%$.

Setelah melakukan analisis data penelitian, diperoleh hasil berupa kemampuan pemecahan masalah matematika yang berbeda dari setiap siswa. Perbedaan ini sejalan dengan pendapat Widyastuti $(2015,185)$ yang mengatakan bahwa setiap siswa dalam menyelesaikan masalah matematika memiliki cara yang berbeda - beda sesuai dengan karakteristiknya masing - masing. Berdasarkan hasil pengerjaan soal tes kemampuan pemecahan masalah yang telah dikerjakan oleh dua subjek yang berasal dari kategori siswa yang memperoleh nilai hasil tes tinggi dan yang rendah menurut teori Polya sebagai berikut:

\subsection{Memahami Masalah}

Indikator menuliskan apa yang diketahui, terdapat siswa menuliskan apa yang diketahui sebanyak satu kali dari lima soal yang diberikan. Fakta yang diketahui adalah berlaku untuk setiap soal yang diberikan sehingga siswa cukup menuliskannya satu kali. Selain itu, dengan menuliskan apa yang diketahui dari soal berulang sebanyak satu kali, dapat menghemat waktu pengerjaan yang terbatas karena jika apa yang diketahui adalah berlaku untuk soal yang berulang, tentu siswa memahami bahwa apa yang diketahui akan berlaku untuk soal-soal berikutnya. Selain itu Pada indikator menuliskan apa yang ditanyakan, siswa tidak menuliskan apa yang ditanyakan pada setiap soal tes yang diberikan karena keterbatasan waktu. Ini dapat dimaklumi mengingat waktu pengerjaan soal yang sangat terbatas dalam menggunakan model pembelajaran kooperatif tipe TGT. Siswa tidak perlu untuk menuliskan apa yang ditanyakan untuk menghemat waktu pengerjaan soal. Pernyataan ini sesuai dengan pendapat Sholihah $(2016,49)$ yang mengatakan bahwa salah satu kelebihan model pembelajaran kooperatif tipe
TGT adalah dengan waktu yang sedikit, siswa mampu menguasai materi secara bermakna.

Indikator menuliskan syarat yang diperlukan untuk menyelesaikan soal, siswa telah menuliskan syarat yang tepat dalam menyelesaikan soal. Indikasi ini menunjukkan bahwa siswa telah memahami syarat yang diperlukan untuk menyelesaikan soal. Pernyataan ini didukung oleh Rahmat, Suwatno, dan Rasto (2018, 19) yang mengatakan bahwa salah satu kelebihan model pembelajaran kooperatif tipe TGT adalah membuat siswa memperoleh pemahaman yang lebih bermakna terhadap pokok bahasan.

Selain itu, terdapat juga siswa menuliskan syarat yang tidak relevan untuk menyelesaikan soal. Waktu yang terbatas dalam kegiatan pembelajaran menyebabkan terdapat siswa salah dalam menuliskan syarat yang diperlukan untuk menyelesaikan soal. Terdapat juga siswa dengan nilai rendah yang tidak menuliskan syarat untuk menyelesaikan soal. Ini karena waktu yang terbatas dalam kegiatan pembelajaran sehingga menyebabkan terdapat siswa dengan nilai hasil tes rendah yang tidak memperoleh pemahaman materi secara bermakna. Pernyataan ini sejalan dengan pendapat dari Rahmat, Suwatno, dan Rasto (2018, 19) yang mengatakan bahwa salah satu kelemahan model pembelajaran kooperatif tipe TGT adalah kekurangan waktu untuk proses pembelajaran.

\subsection{Membuat Rencana Pemecahan Masalah}

Berbagai jenis rumus yang ditemukan berasal dari hasil diskusi kelompok saat pelaksanaan pembelajaran menggunakan model pembelajaran kooperatif. Pada saat kegiatan diskusi kelompok, siswa saling berbagi pengetahuan tentang cara pengerjaan suatu soal. Dan tentu dalam mengerjakan soal, terdapat berbagai alternatif rumus yang dapat digunakan, terutama rumus-rumus cepat yang dapat membuat siswa menjadi lebih cepat dalam mengerjakan soal. Ini menjadi salah satu dampak positif yang diberikan dari model pembelajaran kooperatif tipe TGT dimana Isrok'atun dan Amelia $(2018,145)$ mengatakan bahwa salah satu kelebihan dari model pembelajaran kooperatif tipe TGT adalah siswa mendapat keterampilan dalam bekerja sama.

Siswa yang keliru dalam memilih simbol operasi matematika yang cocok dengan rumus yang digunakan. Ketidakcocokan tersebut dapat mengakibatkan siswa melakukan kesalahan dalam perhitungan, menafsirkan rumus, maupun menyatakan jawaban yang diperoleh. Kekeliruan ini disebabkan oleh keterbatasan waktu pembelajaran yang mengakibatkan siswa menjadi tidak optimal dalam memahami materi yang 
diajarkan. Selain itu, ditemukan siswa dengan nilai hasil tes kemampuan pemecahan masalah dengan nilai hasil tes rendah yang melakukan perencanaan, namun tidak tuntas hingga akhir karena keterbatasan waktu dalam berpikir sehingga mengakibatkan perencanaan yang dibuat menjadi tidak tuntas. Ketidaktuntasan tersebut disebabkan oleh karena kekeliruan dalam menafsirkan jawaban yang diperoleh. Selain itu, ditemukan pemilihan rumus yang tidak sesuai untuk menyelesaikan soal dari salah satu siswa yang memperoleh nilai hasil tes kemampuan pemecahan masalah matematika rendah. Di mana, rumus yang dipilih tidak dapat digunakan dalam menyelesaikan soal. Peneliti berpendapat bahwa siswa tersebut berusaha mengingat kembali beberapa pilihan rumus yang dapat digunakan. Namun karena keterbatasan waktu, akhirnya siswa tersebut tidak memiliki cukup waktu untuk dapat menentukan rumus mana yang sesuai. Pernyataan ini sejalan dengan pendapat dari Rahmat, Suwatno, dan Rasto (2018, 19) yang mengatakan bahwa salah satu kelemahan model pembelajaran kooperatif tipe TGT adalah kekurangan waktu untuk proses pembelajaran.

\subsection{Melakukan Rencana/ Perhitungan}

Siswa dalam melakukan proses perhitungan terdapat kekeliruan. Kekeliruan ini berasal dari salah satu siswa yang memperoleh nilai hasil tes kemampuan pemecahan masalah matematika tinggi. Kekeliruan tersebut berupa ketidaktelitian dalam mensubstitusi nilai variabel yang sesuai kedalam rumus yang benar. Kekeliruan ini disebabkan karena waktu pengerjaan soal yang terbatas sehingga sangat besar kemungkinan bagi siswa untuk melakukan kesalahan. Siswa dengan nilai hasil tes kemampuan pemecahan masalah tinggi yang kurang lengkap dalam menjalankan proses perhitungan. Kekuranglengkapan tersebut terjadi karena kekurangtelitian akibat dari terbatasnya waktu pengerjaan soal sehingga sangat besar kemungkinan siswa melakukan kesalahan dalam proses perhitungan. Pernyataan ini sejalan dengan pendapat dari Rahmat, Suwatno, dan Rasto $(2018,19)$ yang mengatakan bahwa salah satu kelemahan model pembelajaran kooperatif tipe TGT adalah kekurangan waktu untuk proses pembelajaran. Di mana dalam hal ini, waktu pelaksanaan tes juga menjadi bagian dalam proses pembelajaran.

Ditemukan juga kekeliruan dalam proses perhitungan yang dilakukan oleh salah satu siswa yang memperoleh nilai hasil tes kemampuan pemecahan masalah matematika rendah. kekeliruan tersebut berupa kesalahan operasional dalam menggunakan rumus yang diperoleh. Kesalahan ini sebagai akibat dari kesalahan dalam memproses informasi yang diperoleh saat diskusi kelompok. Kekeliruan ini diperkuat dari hasil wawancara terhadap salah satu siswa yang memperoleh nilai hasil tes rendah, diperoleh informasi bahwa siswa tersebut menjelaskan langkah operasional dari rumus yang dipilih, namun langkah yang dijelaskan tersebut adalah salah. Siswa dengan nilai hasil tes kemampuan pemecahan masalah rendah yang menjalankan proses perhitungan, namun belum tuntas hingga akhir. Ketidaktuntasan ini disebabkan karena kesalahan dalam menginterpretasi angka yang diperoleh dari hasil perhitungan. Di mana angka yang diperoleh bukan menjadi jawaban akhir. Kesalahan ini sebagai akibat dari kesalahan dalam memproses informasi yang diperoleh saat diskusi kelompok.

Menurut Ilela, Laamena dan Tamalene (2021) hal ini disebabkan karena kemampuan mengoneksikan informasi yang lemah. Siswa tidak mampu mengoneksikan informasi yang diketahui dan informasi baru yang harus diselesaikan. Siswa tidak mampu menghubungkan antarkonsep kemudian mengorganisasikan ide-ide untuk memahami materi dan menyelesaikannya.

Kesalahan ini diperkuat karena dari hasil wawancara terhadap salah satu siswa yang memperoleh nilai hasil tes rendah, diperoleh informasi bahwa siswa tersebut menjelaskan langkah operasional dari rumus yang dipilih, namun langkah yang dijelaskan tersebut adalah salah. Pendapat ini didukung oleh Isrok'atun dan Amelia $(2018,146)$ bahwa salah satu kelemahan dari model pembelajaran kooperatif tipe TGT adalah bahwa terdapat siswa yang sulit menjelaskan konsep kepada anggota kelompoknya.

\subsection{Memeriksa Kembali}

Siswa yang memperoleh nilai hasil tes kemampuan pemecahan masalah matematika tinggi yang salah dalam menyatakan hasil akhir, namun proses perhitungannya sudah benar. Kesalahan ini diakibatkan karena keterbatasan waktu. Sehingga siswa tersebut menjadi salah dalam menyatakan hasil akhir, padahal proses perhitungannya sudah benar. Selain itu, terdapat siswa yang memperoleh nilai hasil tes kemampuan pemecahan masalah matematika rendah yang salah dalam menyatakan hasil akhir dikarenakan dari tahapan membuat rencana pemecahan masalahnya yang juga salah sehingga menuntun siswa tersebut menuju hasil yang salah.Selain itu, baik siswa yang memperoleh nilai hasil tes kemampuan pemecahan masalah matematika tinggi maupun rendah tidak melakukan pemngujian terhadap kebenaran 
jawaban yang diperoleh dari setiap soal yang diberikan karena keterbatasan waktu. Pernyataan ini sejalan dengan pendapat dari Rahmat, Suwatno, dan Rasto $(2018,19)$ yang mengatakan bahwa salah satu kelemahan model pembelajaran kooperatif tipe TGT adalah kekurangan waktu untuk proses pembelajaran.

\section{Kesimpulan}

Dampak model pembelajaran kooperatif tipe TGT terhadap kemampuan siswa dalam menyelesaikan masalah berdasarkan teori polya adalah sebagai berikut:

a. Memahami Masalah

Langkah dalam memahami masalah tidak lengkap.

b. Membuat Rencana Pemecahan Masalah

i. Menggunakan berbagai alternatif rumus untuk mengerjakan soal.

ii. Melakukan kesalahan dalam menggunakan simbol operasi matematika yang sesuai didalam rumus yang dipilih.

iii. Tidak membuat rencana pemecahan masalah secara tuntas.

c. Melakukan Rencana / Perhitungan

Tidak dapat melakukan rencana/perhitungan dengan sempurna karena (1) adanya kesalahan operasional dalam perhitungan, (2) kurang lengkap dalam melakukan proses perhitungan, dan (3) tidak terselesaikannya proses perhitungan hingga tuntas.

d. Memeriksa Kembali

i. Tidak melaksanakan tahapan pemeriksaan kembali secara sempurna karena (1) salah dalam menyatakan hasil akhir, padahal proses perhitungannya sudah benar, dan (2) tidak melaksanakan tahapan pemeriksaan kembali secara sempurna karena tidak melakukan pengujian terhadap jawaban yang diperoleh.

ii. Tidak melaksanakan tahapan pemeriksaan kembali secara sempurna.

\section{Daftar Pustaka}

Aini, Novita Nurul, dan Mohammad Mukhlis. (2020) "Analisis Kemampuan Pemecahan Masalah Pada Soal Cerita Matematika Berdasarkan Teori Polya Ditinjau Dari Adversity Quotient”. Jurnal
Pendidikan dan Pembelajaran Matematika, 2(1), hlm: $105-128$.

Hadi, Sutarto, dan Radiyatul (2014), "Metode Pemecahan Masalah Menurut Polya Untuk Mengembangkan Kemampuan Siswa Dalam Pemecahan Masalah Matematis Di Sekolah Menengah Pertama". Jurnal Pendidikan Matematika, 2(1), hlm: $53-61$.

Ilela, N. Laamena, Ch, Tamalene, H. 2021. Model Pembelajaran Core, Scramble, Hasil Belajar, dan Operasi Hitung Bentuk Aljabar. Journal of Honai Math. Vol 4 nomor 1. 85-100

Ilmiyana, Miftahul. (2018) "Analisis Kemampuan Pemecahan Masalah Matematika Siswa SMA Ditinjau Dari Tipe Kepribadian Dimensi Myer Briggs Type Indicator (MBTI)".Skripsi, Universitas Islam Negeri Raden Intan Lampung. Isrok'atun, dan Rosmala, Amelia (2018). Model-model Pembelajaran Matematika. Bandung: Bumi Aksara.

Laamena, Ch. M. dan Laurens, Th. (2021) Mathematical Literacy Ability and Metacognitive Characteristics Of Mathematics Pre-Service Teacher. Infinity, Journal of Mathematics Education. Vol 10 Nomor 259-270

Lestari, Lesla, dan Deddy Sofyan (2014). "Perbandingan Kemampuan Pemecahan Masalah Siswa dalam Matematika Antara Yang Mendapat Pembelajaran Matematika Realistik (PMR) Dengan Pembelajaran Konvensional". Jurnal Pendidikan Matematika, 3(2),

Lutfiyah, Nur Iffah. "Analisis Kemampuan Pemecahan Masalah Matematika Berdasarkan Teori Polya Pada Siswa Kelas VIII SMP IT Insan Mulia Manokwari”. Skripsi. Universitas papua: 2020.

Munirah. "Sistem Pendidikan Di Indonesia: Antara Keinginan dan Realita". Auladuna, 2(2), 2015: 233-245.

Rahmat, Fitriyane L. Apriliani, Suwatno, dan Rasto. "Meningkatkan Pemahaman Konsep Siswa Melalui Teams games Tournament “. Social Science Education Journal, 5(1), 2018: 15 - 23.

Sholihah, Ai. "Pengaruh Model Pembelajaran Teams Games Tournament (TGT) Terhadap Hasil Belajar Matematika. Jurnal SAP, 1(1), 2016: 45 - 53. Bandung: Nusa Media, 2015.

Wattiheluw, Nurlaila, Syafrudin Kaliky, dan Salmiati Ma'aruf (2018). "Pengaruh Model Pembelajaran Kooperatif Tipe Teams Games Tournament Terhadap Kemampuan Pemecahan Masalah Matematika Pada Materi Matriks Kelas XI SMA Negeri SIWALIMA Ambon". Prosiding, SEMNAS Matematika \& Pendidikan Matematika IAIN Ambon, Ambon: IAIN.

Widyastuti, Rani (2015). "Proses Berpikir Siswa Dalam Menyelesaikan Masalah Matematika berdasakran teori Polya ditinjau dari Adversity Quotient Tipe Climber". Jurnal Pendidikan Matematika, 6(2) 